deposits the corresponding species, Sequoia sempervirens, Alnus rubra, Quercus densiflora, Umbellularia californica constitute 85.44 per cent of the total number of species.

It is customary to speak of the Tertiary Sequoia with two-ranked leaves as S. Langsdorfii; but it may well be specifically inseparable from the existing Redwood. The plants of the Mascall flora are preserved in diatomaceous shale above the Bridge Creek beds and separated from them by sheets of lava. Several trees, such as species of Quercus, Sequoia Langsdorfi, Umbellularia, Salix, Acer, Cornus, Rhus, Cerocarpus, and many others have representatives in the Redwood forests, while there are several other plants which have their modern counterparts in eastern America and elsewhere. The resemblance of the Bridge Creek flora to that of the present Coast Range forests is much closer : among conifers Pinus, Tsuga, Sequoia and Torreya are common to both; among flowering plants Myrica, Corylus, Alnus, Quercus, Berberis, Umbellularia, Fraxinus, Acer, Rhamnus, Cornus and many others, all linking the Oligocene and recent fioras by closely related species.

In the course of the gradual desiccation, since the Oligocene age, of the northern part of the Great Basin-the region through which flows the John Day River-most of the characteristic Redwood associates have disappeared from Oregon, though they have survived in the more humid belt on the western seaboard. The Bridge Creek flora, which is one of many examined by Prof. Chaney and his co-workers, is an example of an association still found in the Redwood belt ; and in essentials it agrees with Tertiary floras recorded from Switzerland, Greenland, Spitsbergen, Siberia and Manchuria. We know that Sequoia flourished in Mid-Tertiary England, in the arctic regions as far north as Ellesmere Land, over a large area in Europe and the Far East, and in many parts of the New World. Why is the genus now confined to a narrow strip of California? No satisfying answer has been given: Prof. Chaney believes, and he is probably right, that "emergence and the consequent withdrawal of epicontinental seas have played an important part in the restriction of the Redwood forests".*

It is impossible in a single article to do more than direct attention to the nature of the work now being done on the reconstruction of some of the Tertiary floras of the New World and their comparison with floras of the present day. From Alaska through British Columbia, Washington and the States farther south are scattered vast stores of plants waiting to be collected and described; there are also large collections in Canadian museums. This field of work is exceptionally rich in promise: it is certain that by adopting the methods so successfully and convincingly employed by Prof. Chaney, who studies the extinct side by side with the recent floras and follows the latter beyond the southern boundary of the United States into Central and South America, it would be possible to follow the development and vicissitudes of the plant-world over nearly the whole length of western North America. Abundant material is available; the workers are lamentably few.

* For fuller information on the Bridge Creek, Mascall and other Tertiary floras and their relation to the modern Redwood Forest, see R. W. Chaney's papers in Publication No. 349 of the Carnegie Institution, Washington, 1925. Also a paper in Publication No, 346, 1927.

\title{
Relations between Pure and Applied Science*
}

By Sir JAMES BATLIIE, O.B.E.,

Vice-Chancellor of the University of Leeds

$\mathrm{T}$ HERE is still a certain amount of misunderstanding of what applied science means, especially on the part of those who draw a hard and fast line between pure and applied science, or of those who tend to regard applied science as of subordinate scientific -interest and importance. There are some who treat applied science with a certain disparagement as being an attempt to adapt science to commercial purposes, a means of increasing wealth rather than of increasing knowledge. This attitude of mind is not perhaps so widespread as it used to be, but it still exists in Great Britain. Institutions such as the younger universities, which from the first seriously took up investigations which fall within the scope of applied science, have on that account been held to have derogated * From a paper entitled "Applied Science in Yorkshire" read
before Section L (Educational Science) of the British Association at wefore Section L (Educational Science) of the British Association at
York on Sept. 5. In addition to the extracts here printed, dealing York on Sept. 5. In addition to the extracts here printed, dealing
with the relationships between pure and applied science, the paper with the relationships between pure and applied science, the paper outlined the development of technical instruction of all types in which have their headquarters in the county, as well as that of special which have their headquarters in the county, as well as that of special
departments instituted in the Universities of Leeds and Sheffield to promote particular industries.

No. 3289, VoL. 130] from the traditional conception of universities. Certainly up to recent years in Great Britain, no such problems were considered to deserve the attention of the academic mind. It was in fact for long held to be a recommendation and a merit that universities only taught and investigated subjects which could be studied in order to acquire knowledge for its own sake, and were useless otherwise except as promoting mental discipline.

It is instructive to observe that this narrow and indefensible outlook on knowledge is changing, and that the older universities are now taking a prominent and leading part in the advancement of applied science. We have only to recall in this connexion the important investigations carried on in both the older universities in the department of agriculture, and the work done in Cambridge to solve the difficult practical problems of cold storage. The institution, a few years ago, of the Department of Scientific and Industrial Research with its corollary, the setting up of the industrial research associations, is rapidly modifying and 
will in time completely transform the former attitude of the public and academic mind to applied science. When the history of universities in Britain comes to be written, it will be found that not the least of the contributions made by the younger universities to the development of academic life is that they led the way in recognising the scientific value and interest of applied science.

Applied science is neither more nor less than an investigation in the laboratory of the processes which are involved in the adaptation of Nature to the service of society in one form or anothera purpose which is surely eminently important and desirable. Some of these processes have been carried on empirically and with relative success for generations, to the great advantage of mankind. A large amount of experience has been accumulated and handed on by tradition, custom and instruction; but such experience has not been critically examined in the light of and by means of scientific method and resources. So far as rules have been arrived at in this way, the experience acquired rests on what we may call rule of thumb. The purpose of applied science is to substitute the rule of scientific law for the rule of thumb.

In other cases the laboratory examination of Nature's processes and material maylead and has led to the discovery of ways and means of adapting Nature to man's service in directions which have not been thought of in the past. In these cases the knowledge of the laws discovered by science precedes the adaptation of Nature's resources to man's use. New industries and manufactures may arise as the result of the antecedent work of the scientific investigator. Even here it must not be assumed that the application of science ceases to be science when the science is applied. The application consists in carrying out in detail the general laws discovered by science; and this in principle is in no way different from the process of verification by practical test which is an essential characteristic of scientific method. In other words, the application of science is a process of science as much as the discovery of the laws which are applied for man's service. Whether, therefore, the process of using Nature for man's ends precedes investigation by the scientist, or scientific investigation precedes and gives rise to the application of Nature to man's ends, is merely a matter of history and does not affect the meaning of applied science.

Applied science is thus quite distinct from the industrial and commercial development of the results of scientific investigation. This development depends on other considerations;--whether the capital is available to commercialise the results, whether anyone has the imagination and resourcefulness to produce an article which will appeal to the public, or whether the adaptation of the results for the use of man is economically profitable at a given time. Faraday's discovery of magnetic induction was of immense potential service to man, but it required time and genius of another order than his to foresee the ways and means to make it available for man's convenience.

Applied science does not differ from pure science by presenting a less difficult problem or by being less scientific than pure science. The sole differentia is that in the former case the results can promote man's desire to bend Nature to the service of the social life of man, while in the latter there is no such reference, at least directly or in the mind of the investigator while carrying on his investigation. The one aims at the active control of Nature, the other at the reflective comprehension of Nature. Both are essential to the fulfilment of man's life, and equally important ways of manifesting the supremacy of mind over Nature on which civilisation rests. Neither is subordinate to the other; and, as experience shows, they reciprocally assist one another, just as any science may produce results of value to another science. Sometimes we find that discoveries in pure science lead to new developments in applied science; sometimes achievements in applied science give suggestions for further investigations in pure science. Indeed there is no pure science, however apparently remote from social welfare, which may not in the long run promote the aim of applied science.

Apart from the fact that it is important to make clear the significance of applied science, the foregoing statement has a direct bearing on the subject with which the paper deals. For the development of applied science in Yorkshire has been governed by the recognition that effective control over Nature's processes, whether carried on in established industries or not, can only be secured by scientific investigation in the strictest sense. In the universities of Yorkshire in particular, applied science and pure science departments have been established from the first alongside one another. This has not been a mere accident, but a settled policy which, for the reasons given, must be considered to be as sound in principle as it has been fruitful in its results, both to the students of science and to those engaged in scientific investigation. The same policy has been adopted in the case of the higher technical colleges in Yorkshire, for example, those of Bradford and Huddersfield, where good work has been done not only on behalf of applied science but also in pure science.

No doubt in the early stages of the history of applied science in Yorkshire primary importance was attached to the practical usefulness of science for technical processes rather than to pure science. The practical mind of Yorkshire was inclined in the first instance to appreciate science for its value in furthering an intelligent interest in the productive industries of the area. This was but natural and not unreasonable; and since those concerned for the promotion of industrial welfare by means of science were, in general, not themselves trained in science, but had heard of or foreseen its value, it was perhaps inevitable that

No. 3289, Vol. 130] 
the conception of applied science was understood in a comparatively narrow sense, as investigation and instruction in the craft side of industry and in the scientific subjects which seemed relevant thereto. The craft side is certainly an essential aspect of applied science, and must always be so if science is to be applied at all. It was only later and rather slowly that it was realised that this aspect merely sets the problem of applied science and that the understanding of the craft does not provide a solution of the questions which industrial processes raise. Still, even this humble beginning gave the start to what has provided a vast scientific undertaking.

The establishment of the Universities of Leeds and Sheffield, which represents the culminating point in the institutional development of applied science in Yorkshire, created new standards and a new outlook in the conception of applied science and its value for industry. Hitherto, applied science in the widest sense had been restricted to the communication of information on and the study of the technique of industrial processes carried on in the area, with some instruction of a rather elementary kind in certain of the pure sciences. The aim was to train or provide craftsmen with an intelligent appreciation of the rules and operations of their respective crafts, so that there might be in industry more competent and efficient workmen. With the advent of the universities and the spirit of detached scientific inquiry which inspires university work, applied science was able to become the critic and investigator of traditional industrial processes and methods, and to place the resources of a wider scientific outlook and knowledge at the service of craftsmanship. This raised instruction in applied science to a higher intellectual level. It could not be merely the communication of traditional knowledge acquired by experience in industry; its aim was not simply to confirm but to transform existing practice in industry by training whole-time students in scientific principles and by promoting scientific investigation of industrial processes. This could not but be to the ultimate advantage of industry though the effects might not be seen for some time and the results might be slow in appearing.

The prosecution of applied science at this higher level had a further important consequence; it suggested and indeed created a graded system of technical training and education with craft instruction in its various forms at one end of the scale and specialised scientific investigation into industrial processes at the other. The first could be appropriately taken over by the technical colleges, the second by the universities. There is at points a certain overlap, perhaps inevitable, between the work of the technical colleges and the universities. But the main distinction is clear between the purpose of the two types of institutions occupied with applied science. The primary business of the technical college is to provide craft teaching at a lower or a higher level, with higher scientific instruction and research occupying relatively a second place in the work of the college ; the main purpose of the university is to provide higher teaching in science and to carry on scientific investigations in applied science, with technical instruction occupying relatively a secondary place in its work.

\section{Obituary}

Sir Bernard Mallet, K.C.B.

SIR BERNARD MALLET, whose death on $S$ October 28 , at seventy-three years of age, we regret to record, was the son of Sir Louis Mallet, a distinguished civil servant. He first entered the Foreign Office, from which he was transferred to the Treasury. $\mathrm{He}$ became a commissioner of Inland Revenue in 1897 and Registrar General in 1909, from which post he retired in 1920. His chief assistant for many years was Dr. Stevenson, who did such admirable statistical work in connexion with inter alia the differential birth rate, labour which never received adequate reward from the Government in spite of the loyal advocacy of his chief. Sir Bernard was president of the Royal Statistical Society in 1916-18, where, as everywhere, his personal influence was most valuable. He was for long an official of the Political Economy Club, and at its dinners must have met every living economist of note. He wrote several books, including a continuing series on the British budgets.

During the last years of his life, eugenics and the cognate subject of population occupied much of Sir Bernard's time. As to the latter, he was president of the World Population Conference held at Geneva in 1927, as a result of which was inaugurated the International Union for the Scientific Investigation of Population Problems, a now flourishing organisation in which he has continued to play an active part. He was a member of the International Federation of Eugenic Organisations, and attended meetings at Paris, Munich and in Dorsetshire. This last was somewhat of a novelty, the head-quarters being at the house of his cousin, Capt. Pitt-Rivers. A paper by him was read at the International Congress at New York this year.

Sir Bernard joined the Council of the Eugenics Society in 1918 and became its president in 1928. About that time the Society received a large bequest from an Australian pastoralist, the exaggerated hopes thus aroused in truth causing no small trouble. The Society prospered greatly under his guidance, the progress made in regard to sterilisation being especially noticeable, whilst several new schemes were set on foot, of which the most noteworthy was the attempt to give practical definition and expression to the concept of negative eugenics both in the sphere of hereditary

No. 3289, Vol. 130] 